Borivoje PETROVIĆ

УДК $811.111: 81^{`} 367.625$

Faculty of Education Sombor

- стручни рад -

University of Novi Sad

\title{
ENGLISH PHRASAL VERBS WITH THE PARTICLES DOWN, OFF AND UP AND PROGRESSIVE ASPECT
}

Summary: This paper examines the temporal semantic properties of English phrasal verbs with the particles down, off and up in the progressive aspect. The analysis includes testing of telicity, dynamicity and stativity components of meaning. The paper also enquires the influence of verb arguments on the change of aktionsart category as well as the commonest denotation of particles as they appear in the corpus examples. The results show that phrasal verbs, whose particles add to the meaning of telicity, become neutral towards this parameter when in the progressive.

Key words: phrasal verbs, aktionsart, progressive aspect, telicity, particles.

\section{Introduction}

The aim of the present paper is to investigate into the phrasal verbs of English which contain the particles down, off and up. The corpus for this examination is taken from The TIME Magazine Corpus of American English (http://corpus.byu.edu/time/) which contains issues from 1923 to 2006. The corpus was searched with the "[vvg] down", "[vvg] off" and "[vvg] up" keywords, and the result was filtered for chunks dating from the year 2000 and on. The results of such query returned 2497 examples. Cases excluded from this result are non-finite forms of the verbs and verbs complements of higher verbs. Also excluded are the examples where the particle makes a three word verb. The final representative sample of examined verbs is 9 with the particle down, 10 with the particle off and 19 with the particle $u p$, which totals 38 verbs, with 47 sample sentences. The bracketed number after the example is the issuing date of the volume that contains the extracted chunk.

The example chunks were semantically examined with and without the particle. The meanings of the verbs were checked in The Longman Phrasal Verbs Dictionary. The judgment of Elizabeth Salmore (hereafter E. S.), an English native speaker from the United States, lecturer at the University of Novi Sad, was useful in understanding the verb situations with equivocal designation.

\subsection{Phrasal Verbs}

The term multi-verb verbs includes three types of combinations: the prepositional verbs, phrasal verbs and phrasal-prepositional verbs. The elements added to the main verb have a neutral label particles, their nature being that of 
both prepositions and spatial adverbs. Palmer (1974:218) and Bolinger (1971:26) use the term "prepositional adverb" (Bolinger rather than "adverbial preposition," since it is "the adverbial rather than the prepositional use that is more relevant for this study."). A special kind of prepositional adverb is an adprep (in the sense of Bolinger [1971:23-36]) a functional unit which acts at the same time as an adverb and preposition, and which originates from compound prepositions.

Phrasal and prepositional verbs can be distinguished by means of semantic and syntactic criteria. Semantic criteria for delimiting free combinations from phrasal verbs consist of three levels of idiomaticity. Syntactic criteria include tests whose purpose is to draw a line between a verb-particle constituent and a verb-preposition construction (particle movement, adverb insertion, single word synonym, passivation etc. - for a full list of syntactic tests see (Kiss 2011:27-33).

\subsection{Aspect and Aktionsart}

"Aspect", the calque translation of the Russian notion "vid", was being defined differently during its history, without general agreement on its scope and function. Aspect is for Brinton (1988:2) "a way of conceiving the passage of time"; in another words: "aspects are different ways of viewing the internal temporal constituency of a situation" (Comrie 1976:3).

The main aspectual division of situations is into perfective and imperfective. "Perfectivity indicates the view of a situation as a single whole, without distinction of the various separate phases that make up that situation; imperfective pays essential attention to the internal structure of the situation." (Comrie 1976:16).

Unlike aspect, which shows the way the time of some situation passes, aktionsart is its semantic characteristic. Aspect is connected to morphology and syntax; aktionsart to semantics. Choosing aspect, one makes a subjective choice of representation; aktionsart is a factual state of the lexicon. For Novakov (2009:26), aktionsart is "a lexical category concerned with the way that some verbal situation is realized, the nature of that situation and its objective characteristics". In order to describe precisely the temporal rules in the verb phrase it is important to observe both its formal and notional properties. Friedrich (1974:5) mentions three kinds of aspectual encoders: "inherent-radical" (lexical aspect), "derivational-thematic" (aspect of the morphosyntax) and "adverbial-compositional" (aspect of interaction between verbs and adverbial and prepositional phrases).

The most influential postulation of aktionsart in English, applicable to other languages, is Vendler's (1967) quadripartite classification of verbal situations into states, activities, achievements and accomplishments. Basing on this division, later researches tended to describe aktionsart as a set of binary features which value every atomic component of a situation's complex semantic structure. Although the feature sets are not persistent with every author, the following features will be assumed precise enough for the description of verbal situations: dynamicity/stativity, durativity/punctuality and presence/absence of a goal. Thus, the states are stative, durative and atelic, activities are durative, dynamic and atelic, achievements and accomplishments are both telic and dynamic, the difference being only in achievement's punctuality i.e., accomplishment's durativity. 


\subsection{Progressive Aspect}

The progressive aspect in English is formed by the verb to be and present participle. Meanings that it conveys, according to Quirk et al. (1985:198), are durativity, incompleteness and temporariness. Dahl (1985:91), after the examination of samples from many languages, concludes that the most widespread meaning of the progressive is "an ongoing activity". Brinton (1985:8-9) lists continuity-development-ongoingness, dynamicity and incompletion as its main characteristics, designating this form as "the clearest, sometimes the only exponent of the category of aspect in English".

Semantics of the progressive restrict it from appearing with certain types of verbs. Developing and durative qualities make it incompatible with features such as stativity and punctuality. Comrie (1976:35) defines progressivity as "a combination of progressive meaning with non-stativity". This makes states and achievements incompatible with this form. Palmer (1974:71) states that duration that states lexically imply makes futile the use of the progressive aspect. The progressive of states produces non-stative reading, while the progressivity of achievements implies that their punctual structure repeats, or that duration, (the inherent quality of progressivity), indicates the time span before the realization of a point-like situation.

\subsection{Particle as a Marker of Telicity}

It is notable that most of particles in phrasal verbs changes the simple verb's temporal semantics and the change is in a way of "adding a concept of a goal or an endpoint to durative situations which otherwise have no necessary terminus" Brinton (1988:168). The most obvious examples of change are those verbs which belong to the activity class, which, after being added a particle, become achievements and accomplishments: seek/seek out, run/run away, read/read out and eat/eat up.

States usually do not occur in phrasal verbs, because the notion of goal is incompatible with the lack of change of state, progressivity or dynamicity. A particle added to a verb which is an achievement functions to "emphasize the intensity and completion of a verbal situation" (Novakov 2005:110), "re-emphasizes the achievement or punctual nature of the verb" (Brinton 1985:174). With an accomplishment verb a particle is principally considered redundant. Nevertheless, their co-occurrence makes "a 'covert' endpoint 'overt" (Elizabeth Traugott, as in Brinton (1985:174); particle "profiles" a goal (Susan Lindner, in Brinton [1985:175]).

Difference needs to be made between the existence of a goal in some situation and the actual achieving of that goal. The goal is an inherent property of a situation, the achieving of a goal depends on the choice of grammatical aspect. Brinton (1985:182) mentions the perfect and egressive aspects as indicators of an achieved goal, and imperfective as a sign that a goal was not achieved. 


\section{Corpus Analysis}

Particles included in this analysis are down, off and $u p$. All three particles are productive in English, up being the most productive, followed by off and down. The presupposition is that the particles create a resultative meaning, i.e., they should add to the notion of a goal to atelic simple verbs.

\subsection{PARTICLE DOWN}

Particle down has two principal values. The first is a "purely directional" meaning, or "metaphorically transferred directional meaning". However, an additional denotation of this particle is that of "diminution or complete cessation" (Kennedy 1920:19). Regarding its aspectual power, down may shift the aktionsart class of a simple verb.

\section{Chase down}

1. O.K., there's a Google Images window open, where he's chasing down pictures of Keira Knightley. (27.03.06)

The particle in this combination adds the notion of goal to the activity verb chase. The verb chase down is an accomplishment with +dynamicity, +telicity and +durativity features. Since the object of the verb is a noun phrase with an unspecified plural noun head ${ }^{1}$, the situation turns into an activity. The progressive aspect of this verb shows the situation as ongoing. The plural object noun implies that the action is iterative (performed more than once).

\section{Clamp down} (18.09.00)

Spurred by thousands of complaints, the state is clamping down.

The punctual situation clamp in (2) is added a particle with a figurative directive meaning. The phrasal combination yields a +dynamic, -durative, +telic situation, i.e., an achievement. When in the progressive this verb is seen as incomplete, with the goal parameter neutralized.

\section{Close down}

Local businesses are closing down, farm laborers are leaving and ranchers are selling off their livestock. (16.02.01)

The particle down in this example has a meaning of complete cessation of some action. The punctual close turns into an accomplishment after the particle is added, but, the unspecified plural subject noun phrase turns the situation into an activity. In the progressive, the situation has a meaning of an iterative ongoing action.

\section{Crack down}

The National Association of Securities Dealers is cracking down, telling brokerages to send out refunds possibly worth tens of millions of dollars. (08.09.03)

To crack down has a meaning of "become stricter in policies" (Gadsby 2000:108), which means that the combination is idiomatic. This situation type of the phrasal verb is achievement. Taken in the progressive aspect, it is seen as ongoing with a neutralized goal.

\footnotetext{
${ }^{1}$ This cumbersome type of construction will be in further text substituted with the less precise but convenient "the unspecified plural noun phrase object", "singular noun phrase object", etc.
} 


\section{Get down}

These days Charlap's career is getting down deep too. (22.11.04)

The particle down in this example has a meaning of complete fall. The situation get down is an accomplishment - durative, dynamic situation with an implied goal. When in progressive aspect, the notion of telicity is neutralized, i.e., the implication of a reached goal is not overtly readable.

\section{Hunt down}

...place on the border in Paktia province, where some 1,000 allied troops are hunting down about 100 al-Qaeda and Taliban fighters. (27.12.02)

Down in hunt down carries the meaning of completion, i.e., the situation in (6) denotes "chasing (someone) and catching (him)" (Gadsby 2000:254). From the point of view of duration it is a durative, and of telicity - telic situation. The telic phrasal verb with a specified plural object noun phrase renders a telic situation. In the progressive, the situation is a durative iterative activity; the action that lasts certain time is performed multiple times by multiple subjects.

\section{Lay down}

Subsequent government reports that the insurgents were laying down their weapons and fleeing toward the Kosovo border proved groundless. $(02.04 .01)$

The situation lay down, according to E. S. speaker, is a durative, telic and dynamic situation. With a specified plural object noun phrase it does not change its accomplishment aktionsart class. The situation (with the object noun phrase included) put in the progressive is a durative iterative situation (plural subjects and objects) with incomplete state of reaching a goal.

\section{Shut down}

...anthrax report, the targets here were multiplying, and our commandand-control facilities were shutting down one by one. (05.11.01)

The phrasal verb shut down in the example (8) has certain duration in its lexical meaning, so we can say that it belongs to the group of accomplishments. Taken with its complements the class of the situation does not change, since the object noun phrase "one by one" may be seen as a definite quantity. The progressive aspect sees this situation as durative iterative: the equal sets of actions are performed consecutively on many subjects.

\section{Turn down}

Around that same time, another young winemaker, Ken Brown, was turning down job offers in Napa to head even farther south, to the Santa Maria Valley (17.09.01)

The particle in this phrasal verb adds to the concept of total detachment. To turn down has an achievement reading. The set of distinctive features of the verb alone is +dynamicity, -duration and +telicity, but since the object argument is an unspecified plural noun phrase, the situation is -telic. In the progressive, the situation is seen as iterative (the plural object noun) and ongoing.

\subsection{PARTICLE OFF}

In the investigations of Kennedy (1920:20), the particle off makes the relation of "separation or departure" in combinations which it creates. Besides its aspectual force, this particle may also convey the meaning of removal of matter from a surface or a "centrifugal" movement. (Bolinger 1971:104). 


\section{Cool off}

...lapping the Gaza Strip on a steamy night last June, the killer was cooling off with a swim. For a wanted man, he seemed rather audacious, relaxing (05.04.04)

In the combination cool off the particle functions as a marker of telicity of the activity verb cool and makes out of this combination an accomplishment, with a certain period of duration inherent in the lexical substance. When put in progressive, this situation depicts a durative continuative occurrence.

\section{Count off}

On his thick fingers, he is counting off the names his political enemies hurl at him: "Hard-liner. Extremist. Rightist. (27.11.00)

Behind him two Tibetan monks are counting off their prayer beads and whispering. (26.09.05)

The particle off marks the telic aktionsart when added to an activity verb like count. With a definite noun phrase object, count off the names... is an accomplishment, which is, in the progressive, interpreted as a durative iterative situation (plural object noun). The example (12), which has telic interpretation when nonprogressive, in the progressive is seen as incomplete and repeating.

\section{Die off}

Coral reefs are dying off as the seas get too warm for comfort. (09.04.01)

This example sentence contains the verb die off. The verb die, a clear example of achievements, with the added particle becomes an accomplishment. The non-punctual reading of phrasal verbs containing die is possible only with plural subjects (cf Topalov 2008:66). When in progressive, the action is seen as durative iterative and incomplete.

\section{Fend off}

...time when the President's poll numbers are sinking and the West Wing is fending off questions about whether it had a role in exposing a spy... (13.10.03)

With a four-person staff, Hussein is fending off a hacker assault launched by Israelis. (06.11.00)

The particle off in this verb has a meaning of something repelling from the subject. In general sense the meaning it carries is the centrifugal movement from the subject. Taken in the context, the verb fend off is an achievement, roughly paraphrased as "to avoid" (Gadsby 2000:162). The unspecified plural object transforms this situation into an activity. The progressive aspect renders it as an ongoing process.

The example (15) has a singular specified subject noun phrase, which preserves the situation type of the original achievement. In the progressive, the situation is seen as continuative, with unachieved goal.

\section{Fight off}

But the tribe is fighting off attempts by Occidental Petroleum to drill for an estimated 1.5 billion bbl. of oil on... (31.01.00)

Instead, he is fighting off the remainder of 28 lawsuits filed against him between 1998 and 2000. (09.06.03) 
The verb fight presents an activity which, with the added particle becomes an accomplishment. Off as a particle gives the verb a telic quality, with semantics of a centrifugal movement. The argument of the verb in (16), an unspecified plural noun phrase, turns this accomplishment into an activity. This atelic situation in progressive carries the properties of an iterative ongoing process. The sentence (17) contains the verb with a meaning equal to the verb in (16), having different kind of object argument. This definite noun phrase object doesn't affect the accomplishment type of situation. The progressive aspect in the second sentence sees the situation as continuative and incomplete, without the reached goal.

\section{Pay off}

...picking both insiders and outsiders, pragmatists and purists, Bush was not only paying off past favors to constituencies but also, he hopes, building goodwill for the future... (15.01.01)

...space program may be foundering, but its reputation as a mathematicsand-science powerhouse is paying off for its computer programmers. (08.10.01)

Now her failure is paying off again. She has just signed with Island Def Jam Records, a division of... (20.12.02)

The particle off in in the example (18) emphasizes the completion of a telic situation. The particle's semantics denote performing an action to the end. The result of complementing a verb by an indefinite noun phrase object, is a change of the situation type from achievement to activity. In the progressive the situation is seen as ongoing.

The phrasal verbs in the examples (19) and (20) have a meaning different from the verb in (18). They denote "doing something that is worth doing" (Gadsby 2000:356). The verb pay off belongs to the accomplishment class. In the progressive it is seen as ongoing and incomplete.

\section{Rip off}

But the woman rumored to be Martin's girlfriend is ripping off the closet doors to expose Ricky as the greatest Latin lover since Casanova cruised through... (02.04.01)

The aspectual off in (21), that only emphasizes the completive meaning, makes out with the verb an achievement situation. The object noun phrase is specified, and does not affect the telicity of the verb. In the progressive, the situation is seen as ongoing and iterating, with the goal not reached.

\section{Scare off}

Gisele's rate is hardly scaring off clients. (21.02.00)

Some Norwegian salmon fishers complained that Keiko was scaring off their catch, and one scientist suggested he be killed for his own good. (23.09.02)

The particle off in the phrasal combination in (22) denotes a centrifugal movement from the subject. Also, it makes an accomplishment out of an activity. The verb in the first sentence consists of an unspecified plural object noun, which results in conversion of an accomplishment into activity. In the progressive, the situation is seen as iterative, the object being plural. The situation in (23) is, in the progressive, seen as ongoing. Unlike the situation in the first sentence, this is a durative continuative situation. 


\section{Show off}

...administrator was working on baby booties for her niece, a handbag designer was showing off her semi-completed angora scarf, and a few others were struggling to learn the purl... (31.01.00)

The verb show is an achievement verb. With the added particle, which changes the meaning of the simple verb, it is an accomplishment. The progressive aspect of the verb shows the situation as ongoing continuative process.

\section{Swear off}

...birthrates are at record lows; teen crime rates are plummeting; kids are swearing off cigarettes (the smoking rate for high school seniors is the lowest it has been... (26.03.04)

Swear off is a punctual verb, its particle carrying metaphorically transferred directional meaning. The situation type is changed by the mass object noun phrase into an activity. In the progressive this situation is seen as iterating.

\subsection{PARTICLE UP}

$U p$ is considered to involve the most numerous and most diverse combinations with simple verbs. For Kennedy (1920:23) it "occurs in as twice as many combinations than [the second most productive] particle out." Bolinger (1971:101) emphasizes variability of combinations that this particle produces, saying that "[its freedom to combine] is roughly comparable with the prefix re-." Kennedy (1920:23) outlines several distinctive uses of this particle: "upward motion" or its figurative extension, "forward motion or the contrary", "bringing into prominence or consideration", "bringing together", as well as many idiosyncratic combinations. $U p$ is also noticed to influence the aktionsart class change of a simple verb. Aspectual force connected to the primary meaning of motion, Bolinger (1971:98) describes as "the direction that most physical acts of completion take". This author also mentions that some meanings of the particle may overlap, especially when one of the meanings is aspectual.

\section{Add up}

...was awarded its mom-friendly moniker by the Texas Breastfeeding Initiative, are adding up the numbers and giving new support to nursing, working mothers. They should. (17.09.2001)

The verb add is a punctual verb, which it remains after adding the particle. The particle in this case has the meaning of bringing things together. The achievement situation type of this verb changes with a definite plural object noun phrase into an accomplishment. Namely, the plural object of punctual verbs shows the situation as repeating, implying, in the same time, the feature of duration. In the progressive, this situation is seen as incomplete and iterative (the plural object noun).

\section{Back up}

The driver is backing up slowly, so as not to scare the deer away before he can get a (13.11.2000) 
Prince is backing up his commitment by starting new training, communications and performance- review initiatives. (20.12.2004)

The particle $u p$ in the example (27) carries the meaning of distancing from a certain point. This meaning of the verb is specific for movement of a vehicle. It is an accomplishment situation which, in progressive context, conveys the notion of a continuative action in progress.

The verb in (28) may be paraphrased as "to support" (Gadsby 2000:11). The situation could be classified as an accomplishment. The progressive aspect gives it the quality of an ongoing process, incomplete in reaching the terminal point.

\section{Blow up}

His pager is blowing up in his sweaty hand. (26.12.2003)

The verb blow up is an inceptive action. The particle transforms an activity into an achievement, giving the verb a new meaning. The particle in this idiomatic combination carries the semantics of completion. The progressive in this example sees the action as ongoing and iterative. It is when "one of the President's key advisers bursts in" that his pager "was blowing up".

\section{Bring up}

Perhaps we need to acknowledge that we are bringing up kids so sheltered from failure, disappointment and consequences that they have no coping skills... (09.04.2001)

To bring up is an idiomatic combination, with the particle having a completive meaning. Unlike the verb itself which is an achievement, the whole situation is an activity, lasting in time in repeating segments (due to the plural object noun). The progressive sees this action as ongoing.

\section{Build up}

I was building up my reserves. (17.04.2000)

$U p$ in this example gives the verb the sense of completion, and acts as a marker of telicity. The complex verb is an accomplishment. Having a definite noun phrase as an object it remains an accomplishment. In the progressive, the action is viewed as lasting in time, with an incomplete goal.

\section{Buy up}

Soon a Who's Who of well-heeled world leaders was buying up Vuitton bed trunks and wardrobe cases. (16.02.2004)

To buy up in (32) means to buy until satiation. Therefore, the particle up marks completion of an iterative punctual process. The object argument is an indefinite noun phrase, which means that the goal parameter is neutralized - the situation becomes an activity. In progressive, the situation is seen as ongoing and iterative.

\section{Dry up}

The ancient wells are drying up. (05.11.2001)

To dry up means that something dries completely. The verb categorizes as an accomplishment situation. The action is, in the progressive, seen as incomplete, with an unachieved goal. 


\section{Finish up}

Dry in stores and Scissors en route to the big screen, Burroughs is finishing up his next book (working title: Magical Thinking). (26.12.2003)

The verb finish up denotes finishing of the last part of something, according to E. S. speaker it "brings a process to a close" and belongs to the class of accomplishments. In the progressive, it is an incomplete ongoing action with the goal neutralized.

\section{Heat up}

...handful of the most doctrinaire die-hards still dispute the idea that human activity is heating up the planet. (26.04.2000)

The particle $u p$ in this phrasal verb has a metaphorical directional meaning which could be described as "to move up a scale". To heat up the planet is an accomplishment situation whose object noun phrase does not alter the situation's aktionsart class. In progressive the action is seen as ongoing, its goal being neutralized.

\section{Look up}

Every year in India, things are looking up. (25.08.2003)

The phrasal verb in (36) originates from the stative meaning of the verb look. The resulting phrasal verb is also a state. Usually unacceptable occurrence of stative verbs and the progressive, in this example can be explained as a contingent (temporary) change of state: things are, with every new year, improving.

\section{Pack up}

Increasingly, families, nuclear and extended, are packing up their cars or boarding planes to escape to greener pastures, whiter beaches or snowier... (16.10.2000)

To pack up in (37) means to finish with packing, to pack completely. The verb belongs to the accomplishment class. In the progressive the action is seen as ongoing, with the goal not reached.

\section{Pile up}

But though Clarke is frank, you never feel he is piling up sordid details just for fun. (10.04.2000)

The particle $u p$ in this example has a meaning of a finished action - the particle acts as a telicity marker. The verb is an accomplishment, which complemented by an indefinite noun phrase object, acts as an iterative activity. The progressive aspect of this situation is seen as ongoing and repetitive.

\section{Play up}

But with the suicide attacks persisting, the Israelis are now playing up the alleged Saudi connection to terrorism -- making it even less likely that Israel will... (20.12.2002)

The meaning of play up is idiomatic and means "to consider something more serious than it actually is" (Gadsby 2000:371). The situation play up the alleged Saudi connection to terrorism belongs to the accomplishments class. The progressive sees it as incomplete, with an unrealized goal. 


\section{Serve up}

Over at Wimbledon, where tennis was actually being played, Venus Williams was serving up her new look on Centre Court: a Diane Von Furstenbergdesigned Reebok tennis dress... (14.02.2003)

To serve up in (40), the same as open up, means that something has become visible (brought into prominence). The situation is an achievement. The singular object noun phrase does not alter the category of aktionsart. In progressive the situation is seen as ongoing and incomplete.

\section{Shake up}

... which had long subscribed to the motto The News Is the Star, was shaking up its management and hiring star talent like anchor Paula Zahn. $(11.02 .2002)$

The phrasal verb shake up is an idiomatic combination meaning "to change drastically the structure of an organization" (Gadsby 2000:455). The particle gives the verb characteristics of a complete situation. With the definite noun phrase object, the verb does not change its accomplishment situation type. In progressive, the verb is seen as ongoing, with a neutralized goal.

\section{Spring up}

Chinese competitors, in particular, "are springing up like mushrooms after a rain." (19.04.2004)

To spring up, meaning "to start to exist" (Gadsby 2000:492), denotes an inceptive action (an action that denotes the beginning phrase of a process). The particle up gives the verb meaning of coming into prominence. The verb is an accomplishment which, in the progressive, owing to the plural object noun phrase, has iterative reading.

\section{Step up}

He has been subpoenaed seven times by grand juries. Law-enforcement task forces are stepping up their investigations, creating a common database to correlate evidence in scores of incidents. (16.03.2001)

Even before the campaign began, Mexico was stepping up deportations -- 93,563 during the first six months of this year, a huge increase... (13.08.2001)

This phrasal verb is idiomatic in meaning, although it can be metaphorically elicited from the joining elements. In that case, the particle would denote progressing on the amount scale. The situation in (43), step up their investigations, is an accomplishment verb which in the progressive has a quality of a developing, unfinished action. The unspecified plural noun phrase object in (44) tells that the situation is unfinished, giving it properties of an activity. In the progressive, this atelic action is seen as ongoing.

Stir up

Orbitz is stirring up a storm by cutting deals it makes sure no one can beat. (30.03.2001)

Shi'ite-Sunni discord is already problem enough for U.S. occupation authorities without al-Qaeda's stirring up more trouble. (23.02.2004)

The particle $u p$ in the verb stir up makes the verb inceptive in its semantics. The situation is an accomplishment, which is in the progressive seen as ongoing and incomplete. The verb in the second example is also an accomplishment which has a definite noun phrase object. 


\section{Whip up}

Slobodan Milosevic was whipping up Serbian nationalism, and the rest of the world was only dimly aware of... (19.03.2001)

Whip up in (47) is a verb which represents accomplishment situations. The definite noun phrase in the object does not change its telicity. Progressive form of the verb sees this action in progress, without reaching a goal.

\section{Conclusion}

This paper dealt with progressive forms of phrasal verbs in English. In the analysis, the glance was taken at the meaning of the particles in the combinations they make. The features of stativity, duration and telicity were examined. It has been seen that situations in progressive are perceived differently depending on their belonging to the certain aktionsart category. Progressive of atelic events does not change much of their temporal semantics. Since it is a situation without a goal we cannot discuss its achievement or non-achievement. The progressive of telic events neutralizes the goal of a situation.

Having the fact that states cannot occur in a progressive form (when they do, their meaning is dynamic) we can say that the progressive aspect of phrasal verbs renders them as ongoing and incomplete. If the goal exists in a situation as the inherent property, progressive neutralizes it. Situations in the progressive can be iterative and continuative. The component that influences the iterative reading is the grammatical number of subjects and objects and the meaning of the verb itself. Iterative accomplishments and activities are seen as multiple stretches on the time line, while iterative achievements are seen as multiple points. The difference between accomplishment and activity stretches is in terminal points that exist on accomplishments and not on activities. Progressive aspect of iterative accomplishments implies that, with each iteration, a new, unfinished segment comes up or, with achievements a new iteration of a point-like event is expected. Continuative situations are one-time occurrences in the temporal frame. A continuative activity is a stretch without terminal points, and continuative accomplishment is a single stretch that has the terminal point. The terminal point is excluded when situations are viewed progressively. Achievements cannot be continuative.

Arguments of the verb phrase have influence on the type of verbal situation. A telic verb with unspecified plural noun or unspecified non-count noun becomes atelic. Specified noun adds to the notion of telicity. An achievement with the specified plural noun makes an iterative accomplishment.

The examined particles in the phrasal verbs may add to the notion of telicity. When a verb is inherently telic, the particles serve as confirmation of the telic nature of the verb; the particles in this case emphasize the telic nature of the situation.

The meanings that the particles in the corpus have are diverse. The particle down may have a directional meaning, but this meaning can also metaphorically shift into figurative movement. An additional meaning of this particle is that of diminution and cessation. The particle off in many cases gives the meaning 
of repulsion; the arguments of phrasal verbs with this particle are seen as moving in a centrifugal direction. The particle up is the clearest example of a particle serving as an aspectual marker. Additional meanings that it bears fall into several categories, among which are: bringing the things together, doing some action until satiation, adding the sense of completion of an action, etc.

\section{References}

1. Ashby, Michael (2001). Oxford phrasal verbs dictionary for learners of English. Oxford: Oxford University Press.

2. Bolinger, Dwight Le Merton (1971). The phrasal verb in English. Cambridge: Harvard University Press.

3. Brinton, Laurel J. (1985). "Verb Particles in English: Aspect or Aktionsart". Studia Linguistica 39: 157-168.

4. Brinton, Laurel J. (1988). The development of English aspectual systems: aspectualizers and post-verbal particles. Cambridge: Cambridge University Press.

5. Comrie, Bernard (1976). Aspect: An introduction to the study of verbal aspect and related problems. Cambridge: Cambridge University Press.

6. Dahl, Östen (1985). Tense and aspect systems. Oxford: Blackwell.

7. Friedrich, Paul (1974). "On aspect theory and Homeric aspect”. International Journal of American Linguistics. Vol. 40, No. 4, Part 2 (OCTOBER 1974): 1-44.

8. Gadsby, Adam (2000). Longman Phrasal Verbs Dictionary. London: Pearson Education Limited.

9. Kennedy, Arthur Garfield. (1920). "The modern English verb-adverb combination". Stanford University Publications, University Series, Language and Literature. Vol. 1. No. 1. Stanford: Stanford University.

10. Kiss, Katalin. 2011. Contributions to a Semantico-Contrastive Analysis of Verb Particle Constructions in English and Verbs with Coverbs in Hungarian. Debrecini: Debreceni Egyetem.

11. Novakov, Predrag (2005). Glagolski vid i tip glagolske situacije u engleskom $i$ srpskom jeziku. Novi Sad: Futura publikacije.

12.Novakov, Predrag (2009). "Aspect and Boudedness". Romanian Journal of English Studies 6: 364-373.

13.Palmer, Frank Robert (1974). The English Verb. London: Longman.

14. Quirk, R, S Greenbaum, G Leech \& J Svartvik (1985). A comprehensive grammar of the English language. London: Longman.

15. Topalov, Jagoda (2008). "Phrasal verbs and progressive aspect". Facta Universitatis - Linguistics and Literature. Vol. 6, No. 1: 60-72.

16. Vendler, Zeno (1967). Linguistics in philosophy. Ithaca: Cornell University Press. 
Боривоје Петровић

\section{ЕНГЛЕСКИ ФРАЗНИ ГЛАГОЛИ СА ПАРТИКУЛАМА DOWN, OFF И UР И ПРОГРЕСИВНИ ВИД}

Сажетак: У овом раду се испитују својства темпоралне семантике енглеских фразних глагола са партикулама down, off и ир у прогресивном виду. Анали-за укључује тестирање теличности, динамичности и стативности. У раду се такође поставља питање утицаја аргумената глагола на промену у категорији акционсарта као и најчешћа значења партикула које се јављају у корпусу. Резултати показују да се код фразних глагола, који са додатом партикулом представљају теличну ситуацију, у прогресивном виду, параметар теличности најчешће неутрализује.

Кључне речи: фразни глагол, акционсарт, прогресивни вид, теличност, партикуле.

Примљено: 13. 10. 2015. године.

Одобрено за штампу: 22. 1. 2016. године. 